\title{
Nineden-Dededen, Toruna; Bilgi ve İletişim Teknojilerine Yönelik Metaforik Algılar
}

\author{
DOI: $10.26466 /$ opus.331307
}

\section{$\underline{\text { Hanife Akgül }}^{\star}$}

* Yrd. Doç. Dr, Çanakkale Onsekiz Mart Üniversitesi, Eğitim Fakültesi, Çanakkale/Türkiye E-Posta: hanifeakgul@comu.edu.tr

ORCID: $\underline{0000-0001-8543-9343}$

\section{Öz}

Günümüzde bilgi ve iletişim teknolojilerinde hızlı değişim ve gelişme yaşanmaktadır. Bu değişim ve gelişmeye gençler ve çocuklar çok hızlı uyum sağlarken, yaşlıların bu hızı yakalayamadıkları söylenebilir. Bu çalışmanın amacı, ninelerin, dedelerin ve torunlarının bilgi ve iletişim teknolojilerine ilişkin algılarını metaforlar yoluyla belirlemektir. Araştırma nitel bir araştırmadır. Gönüllülük esasına göre belirlenen toplam 40 kişi araştırmanın örneklemini oluşturmuştur. Araştırma 2016 yılında Kayseri ilinde yaşayan 65 yaş ve üstü 20 nine veya dede ile bunların torunları olan 20 çocuk üzerinde gerçekleştirilmiştir. Araştırma kapsamındaki katılımcılara "Bilgisayar/tablet ale benzer; çünkü " biçimindeki birkaç cümle verilerek, görüşleri alınmıştır. Katılımcıların bilgisayar teknolojilerine ilişkin algıların hangi metaforlarla ortaya koyacakları hem de ortaya çıkacak metaforların ortak özellikleri belirlenmeye çalışılmıştır. Elde edilen verilerin değerlendirilmesinde nitel araştırma desenine uygun olarak içerik analizi yöntemi kullanılmıştır. Bilgi ve iletişim teknolojilerine ilişkin metaforlar kategorilere ayrılmıştır. Bu kategoriler "Zaman geçirme aracı", "Zararlı icatlar" "Zaruri ihtiyaç", "Hayatı kolaylaştıran icatlar" şeklinde oluşturulmuştur. Bilgi ve iletişim teknolojilerini torunlar olumlu metaforlarla ifade ederken; nine ve dedeler olumsuz metaforlarla yorumlamışlardır.

Anahtar Kelimeler: Bilgi ve iletişim teknolojileri, nine, dede, torun, metafor

1 Bu çalışmanın bir kısmı "3. Uluslararası Çin'den Adriyatik'e Sosyal Bilimler Kongresi”nde sözlü bildiri olarak sunulmuştur. 


\title{
From Grandparents to Grandchildren: Metaphoric Perceptions Concerning Information and Communi- cation Technologies
}

\author{
DOI: $10.26466 /$ opus.331307
}

\begin{abstract}
Rapid changes and developments have occurred for information and communication technologies in today. While the youth and children adapt to these changes and developments very quickly, the elderly are not able to catch this speed. The aim of this study is to determine perceptions of grandparents and their grandchildren concerning information and communication technologies through metaphors. This is a qualitative study. The sample of the study consisted of a total of 40 people who were determined based on voluntariness. The study was conducted on 20 grandmothers or grandfathers, aged 65 years and older, who were living in the city of Kayseri, and 20 children who were their grandchildren, in 2016. Opinions of the participants included in the study were taken by giving several sentences in form of "Computer/tablet is like................; because....." to them. It was tried to determine with which metaphors the participants will reveal their perceptions concerning computer technologies and also common characteristics of metaphors. Content analysis method was used as appropriate to qualitative research design for evaluation of the obtained data. Metaphors concerning information and communication technologies were categorized. These categories were formed as "Time-wasting tool", "Harmful inventions", "Essential needs", "Inventions making the life easier". While the grandchildren expressed information and communication technologies by using positive metaphors, the grandmothers and grandfathers commented them by using negative metaphors.
\end{abstract}

Key Words : Information and communication technologies, grandmother, grandfather, grandchildren, metaphor 


\section{Giriş}

Günümüzde bilginin hızlı artışı ve bilgiye erişimde teknoloji kullanımıyla beraber bilgi ve iletişim teknolojileri kavramı hayatımıza girmiştir. Bilgi teknolojisi, bilginin yaratılması, toplanması, biriktirilmesi, işlenmesi, yeniden elde edilmesi, yayılması, korunması ve bunlara yardımcı olan araçlar olarak tanımlanmıştır (Akkoyunlu, 1998; akt. Eyidoğan, 2009). İletişim teknolojisi; insanlar arasında iletişim ve haberleşmeyi sağlamaya yarayan, bilgiye erişebilmede ve bilginin ortaya konulmasında kullanılan telefon, faks, modem, televizyon, bilgisayar ve internet gibi uzaktan iletişim donanımlarını tanımlamada kullanılmaktadır (Akkoyunlu, 1998; akt. Eyidoğan, 2009; UNESCO, 2003). Bilgiye ulaşmada kullanılan teknoloji, alet ve araçlar aynı zamanda iletişim amaçlı da kullanılmaya başlanmış ve böylece iletişim teknolojisi ve bilgi teknolojisi birleşerek birlikte kullanılmaya başlanmış; bilgi ve iletişim teknolojileri (BİT) kavramı oluşmuştur. Bilgiye ulaşma, iletişim kurma veya çevreye elektronik veya dijital araç gereç kullanarak etkide bulunmayı sağlayan her şeye BİT denir (Siraj-Blatchford ve Siraj- Blatchford, 2003). Bir başka tanıma göre ise BİT, bilgiyi iletmek, işlemek, yaratmak, yaymak, paylaşmak, depolamak ve yönetmek için kullanılan bilgisayar, telekomünikasyon, internet vb. elektronik kaynaklar ve servislerdir (Jankowska, 2004). Rouse (2005) tanımında BİT'in çeşitli şekillerine vurgu yapmıştır. BİT; radyo, televizyon, cep telefonu, bilgisayar, ağ donanım ve yazılımları, uydu sistemleri ve tüm bunlarla alakalı video konferansı veya uzaktan eğitim gibi iletişim cihaz ve uygulamalarının bütünüdür demiştir. Genel olarak BİT; Elektronik ortamda bilgiye ulaşma, elde etme, kaydetme, düzenleme, depolama, yaratma, kullanma, sunma ve paylaşma olanağı veren donanım (bilgisayarlar, tarayıcılar, dijital kameralar, v.b) ve yazılımları (veritabanı ve çoklu ortam programları); telefonlar (sabit, mobil), belge-geçerler, modemler, bilgisayar, televizyon, video, DVD, radyo, uydu sistemleri gibi bilgiye erişme ve kullanmayı sağlayan telekomünikasyon araçlarını ve bu teknolojiler tarafından sağlanan video konferans ve e-posta gibi hizmetlerini tanımlamak için kullanılan terimdir (UNESCO, 2006).

Son yıllarda bilgi ve iletişim teknolojilerinin hızla yayıldığını görmekteyiz ve bu yayılma hızı artarak devam etmektedir. Türkiye 
İstatistik Kurumu verilerine göre; 2004 yılında hanelerde bilgisayar kullanım oranı \%23.6 iken 2015 yılında bu oran \%54,8'e, internet erişim oranı ise \%7'den \%69,5'e çıktığı görülmektedir (Türkiye İstatistik Kurumu, 2015). Özellikle internetin yaygınlaşması, bilgiyi elde etme yollarında ve iletişimde teknoloji kullanımını önemli ölçüde arttırmıştır. Teknoloji kullanımının artması ise yine bilgi paylaşımını arttırmış ve bilgiyi daha kolay ulaşılabilir hale getirmiştir ve günlük hayatı hızlandıran BİT oldukça hızlı gelişen devasa bir bilgi kaynağı da yaratmıştır. Böylesine geniş çapta bilgi muhafazası sonunda ilk kez 1968'de Kohyama tarafından kullanılan "Enformasyon Toplumu" metaforunu doğurmuş; buna karşın 1990"lı yılların başında ise daha çok bilginin ekonomik değer ifade etmesi ile ilgili olan "Bilgi Toplumu" metaforu belirmiştir (Anderson, 2008). Bu karşı konulamaz yaygınlaşma birçok yarar sağladığı gibi beraberinde bazı endişeleri de getirmiştir. Bu endişelerden en çok göze çarpanı BİTecin kısa ve uzun vadede bireylere ve topluma düzen mi yoksa kargaşa mi getireceği sorusunda vücuda gelmektedir (Zittrain, 2008; Miller ve Slater, 2001). Örnegin internetin sosyal destek, kimliğin keşfi, kişilerarası ilişkiler ve kritik düşünme becerisinin gelişimi yanında bilgiye kolay ve çabuk yoldan ulaşma ve akademik destek gibi eğitsel faydaları varken, son yıllarda dikkatler sanal ortamda karşılaşılan bazı riskler ve giderek internette daha çok zaman geçirme gibi potansiyel bağımlılıklar üzerinde yoğunlaşmaktadır (Aksaray, 2011). BİT ile birlikte hayat hızlanmış ve bilginin önemi artmış, teknolojik bir yenilik insanın günlük hayatını derinden etkilemiştir. BİT'in bireylerin düşünüş ve yaşayış çizgisinde kırılmalara yol açtığı söylenebilir. Yeni bir kültür yarattığı iddia edilen BİTecin hayata etkisi ile bireylerin kendilerini bu yeni kültüre uymaya mecbur hissetmeleri kaçınılmazdır (Williams, 2001). Bilgi ve iletişim teknolojilerinin toplumdaki her kesimden bireyin yaşamını etkilediğini söylemek mümkündür. BİT, günümüzde pek çok farklı kişi tarafından pek çok farklı alanda kullanılmaya başlanmış ve günlük yaşamın ayrılmaz bir parçası haline gelmiştir (Haugen, 1998).

Yaş, bireylerin teknolojiyle olan ilişkilerinin belirlenmesinde, günümüzde belirleyici bir faktör olarak karşımıza çıkmaktadır. Teknolojik yenilikler yaşlıların bağımsızlıklarını ve refahlarını arttırsa da gençlerle karşılaştırıldığında ürün, hizmet ya da düşünceyi içeren yenilikleri en son benimseyen grubun yaşlılar olduğu görülmektedir. 
Teknolojik yeniliklere uyum sağlama, hem bilişsel (farkındalık ve ilgi) hem de davranışsal (deneme ve kabullenme) aşamaları içeren bireysel bir karardır (Özkan ve Purutçuoğlu, 2010). Yaşlılık, yaşam sürecinde gelişme ve olgunlaşmanın ardından kendine özgü fizyolojik ve ruhsal değişimlerin ortaya çıktığı evredir, genel olarak algılama, bellek ve yaratıcılık yeteneklerinin azalması ile kendini belli eden durumdur (Akgül, 2016). Teknolojinin hızlı bir şekilde ilerlemesi ise teknolojik aletlere yeni özellikler yüklemektedir. Her gün hatta her dakika yeni bir teknolojik ürün geliştirilmektedir. Aynı zamanda yaşlanarak öğrenme oranı da azalmaktadır. Böylece BİT yaşlılar için takip edilemez, öğrenmesi güç bir hale gelmektedir. Bunu birçok nedene bağlayabilmek mümkündür. Yaşlılardan birçoğu için geçmişte öğrendikleri ve gördükleri teknoloji dışında teknoloji hakkında pek bilgileri yoktur. Televizyon ve radyo gibi bazı teknolojik cihazların kullanımı çok çabuk kabul görürken akıllı telefon gibi cihazların kullanımının gözle görülür oranda düşüktür. Hatta yaşlılar nispeten kullanımı daha kolay olan eski telefonlara yönelmektedir. Hatta cep telefonları kullanamayan yaşlılar da vardır (Dönmez, 2012). Günümüzde epey gerekli olan cep telefonlarının her dakika yeni bir modeli çıkmaktadır. Böylece öğrenmekte bir hayli zaman almaktadır (Dönmez, 2012). Oysaki BİT yaşlıların hayatını kolaylaştıracak ve onları mutlu edecek birçok hizmeti sunmaktadır (İnternet bankacılığı, E şifre kullanarak kurumsal işlemleri yapabilmek, internet ve akıllı telefonla çevreyle iletişim kurmak ve yalnızlık yaşamamak) (Ekici ve Gümüş, 2016). Yaşlıların bir kısmının BİT kullanımları ve ilgileri düşük olmasına rağmen, BİT ile ilgilenen, kendini genç hissederek teknolojik aletleri öğrenmeye istekli ve bunları iyi kullanabilen birçok yaşlıda mevcuttur. "Yaşlı Tüketiciler ve Teknoloji" konusunda araştırma yapan Öztürk ve Özata (2012) yaşlı tüketicileri, teknolojik ürünlere yönelik tutumlarına göre "Teknoloji Karşıtları, Teknoloji Aşıkları/ Kullanıcıları, Teknolojiye Ayak Uyduramayanlar, Teknolojiden Bihaberler" diye dört gruba toplamıştır. Teknolojinin öneminin farkında olan yaşlılar, teknolojiyi ilerlemenin/gelişimin doğal bir sonucu olarak görmekte ve paralelinde teknolojik yenilikleri kabullenmek zorunda olduklarını bilmektedirler (Özkan ve Purutçuoğlu, 2010). 
BİT açısından incelenmesi gereken diğer bir yaş grubu ise çocuklardır. Çocukluk döneminde sosyal gelişimi etkileyen bir takım unsurlar bulunmaktadır. Bunlardan bazıları; aile, kardeşler, akranlar, cinsiyet, çocuğun engel durumu, yaş, oyun faaliyetleri, kitle iletişim araçları, televizyon, internet, bilgisayar, okul ve eğitimdir. Çocuğun sosyal, bilişsel, dil gelişimi ve diğer tüm gelişim alanları bu faktörlerden zaman zaman etkilenmektedir (Akbaş, 2008). Bazı çocuklarda gelişimi desteklemek, sadece tek bir materyalle mümkün olmamaktadır. Günümüzde tablet bilgisayarlar, televizyonlar, bilgisayarlar, internet gibi birçok teknoloji onlara sunulmaktadır. Çocuklar yaşadıkları bu çevrede artık bahsedilen aletlerden uzak kalamamaktadır. Çocuklardan birçoğu bilgisayar, internet, tablet gibi BITT ve bu tür öğrenme metotlarından daha iyi anlayabilmekte ve öğrenebilmektedirler (Dereoball, 2010). Kısaca BİT çocuklarda; dil gelişimini desteklemek için kullanılabilir, matematiksel düşünme ve problem çözme becerilerini desteklemek için kullanılabilir, farklı kültür ve dil özgeçmişine sahip çocukların desteklenmesinde kullanılabilir, özel eğitime muhtaç çocukların eğitimini desteklemek amaçlı kullanılabilir. Çocuklara hitap edecek şekilde tasarlanan, sadece görsel bir bakış, klavye veya fareden daha fazlasını sunan ürünler gittikçe artmaktadır (Resnick ve diğerleri, 1998). Tüm bunlar göz önüne alındığında çocukların bu teknoloji dünyasının içerisinde yaşarken bu elektronik oyuncaklardan, bilgisayardan, telefondan, internetten, televizyondan, dijital fotoğraf makinesinden, video oyunlarından, nasıl etkilendikleri, onları kullanma biçimleri araştırılmalıdır. Bu metaforlar bunu ortaya koyabilir.

Bilgi ve iletişim teknolojileri günümüzde hayatımızın gerekli bir parçası haline gelmiştir. BİT içerisinde kullanımda en önde gelenlerin çoğunlukla bilgisayar, cep telefonu ve internet olduğu söylenebilir (Anderson, 2008). Bu nedenle bu araştırmada çocukların ve yaşlıların bu araçlara ilişkin metaforik algıları belirlenmeye çalışılmıştır.

Metafor, bir kavramın bireyde oluşturduğu etiket, anlam ya da kavramsal ifadelerdir. Bireylerin basit olarak bir kavramı bir başka kavramla açıklamasından daha önemli ve güçlü bir zihinsel üretimdir çünkü ilgili kavrama dönük sahip olunan derinliği ve deneyimleri ifade eder (Eraslan, 2011). Metafor kelimesi, Yunanca "metaphoradan" ya da "Metafora" köklerinden türemiştir. "Meta" öte, değiştirmek, "pherein" ise taşımak, yüklenmek, katlanmak kelimelerinden oluşmuş, bir yerden 
başka yere taşımak anlamındadır (Levine, 2005). Metafor insanların dünyayı görme ve anlam çıkarma biçimi şeklinde vurgulanmaktadır (Morgan, 1980). Türkçede metafor kavramı; benzetmeler, istiareler ve mecazlar şeklinde kullanılmaktadır. Bu kullanımlar metaforun bir olguyu ya da nesneyi yeniden kavramsallaştırma, değişik açılarıyla bağlantılama ve ifade etme özelliğini belirtmektedir (Aydın ve Pehlivan, 2010: 818; Eraslan, 2011:3). Metaforlar, kelimenin gerçek manasından farklı kullanılır, benzetmeyi amaçlar ve kelimenin asıl manasında kullanılmasını ortaya çıarır (Yıldırım ve Şimşek, 2016). Cerit (2008), metaforları insanların hayatı, çevreyi, olayları ve nesneleri nasıl gördüklerini farklı benzetmeler kullanarak açıklamaya çalışmada kullandıkları bir araç olarak tanımlar. Metaforlar, insanın doğayı ve çevresini anlamasının, anlamsız gibi görünen nesnel gerçeklikten belirli yorumlar yoluyla anlamlar çıkarmasının, yaşantı ve deneyime anlam kazandırmanın araçları olarak "bilmeye" de olanak sağlamaktadır (Yıldırım ve Şimşek, 2016). Genel olarak bir kavramın daha tanıdık ve bilinen terimlerle ifade edilmesi olarak tanımlanan metafor terimi bireyin kendi dünyasını anlayarak yapılandırmasına imkan sağlayan güçlü bir zihinsel haritalama ve modelleme mekanizmasıdır (Arslan ve Bayrakçı, 2006). Koç (2014) ise metaforu, "bireylerin somut ya da soyut herhangi bir olgu, durum ve/veya süreç hakkındaki algı ve tutumlarının belirlenmesini sağlayan, söz konusu unsurlara yönelik zihinlerinde yer alan kavramsal karşıllklar" şeklinde tanımlamıştır. Metaforlar yardımıyla pek çok soyut kavram zihnimizde önceden oluşturulmuş şemalara daha kolay yerleştirilmektedir (Doğan, 2015).

Bireylerin basit olarak bir kavramı bir başka kavramla açıklamasından daha önemli ve güçlü bir zihinsel üretim olan metaforlar, ilgili kavrama dönük sahip olunan derinliği ve deneyimleri ifade etmektedir (Eraslan, 2011). Sadece bir söz figürü değil aynı zamanda bir düşünce figürü olan metafor (Lakoff ve Johnson, 2005), insanın kendini ifade edişi üzerinde de biçimlendirici bir etki yaratmaktadır (Morgan, 1980).

Metaforlar;

- Yürütülen çalışmaları tekdüze ve sıkıcı bir yapıdan kurtarmakta; alışılagelmiş tekniklerin dışında yeni bir alternatif oluşturmaktadir. 
- Yaratıcı düşünmeyi destekleyen, farklı bakış açılarını ortaya koyma imkânı sunan, belli başlı sınırlar çerçevesinde değil tamamen bireylerin düşünce sistemine göre ilerleyen özgürlükçü bir çalışma ortamı sağlamaktadır.

- Çalışmaların içerik olarak derinlik kazanmasının yanısıra işleyişin de pratikleşmesine katkı sağlamaktadır. Onlarca maddenin yer aldığı anket çalışmalarına kıyasla katılımcıların bu tarz sorulara daha içten cevaplar verdiği görülmektedir.

- Bireylerin kendilerini birden fazla sözcük ile dahi eksik ifade edebilecekleri pek çok durumda, düşünceleri net bir şekilde tek bir sözcük ile çok daha kısa bir zaman zarfı içerisinde ortaya koyabilmelerine imkân sunmaktadır.

- Belirlenen kavramın farklı kavramlara benzetilmesi sonucunda bağ kurma, karşılaştırma yapılmasını sağlamaktadır.

- Araştırmacıların bilinen ya da tahmin edilen gerçeklerin ötesinde görülmeyeni görmelerini, detayları fark etmelerini ve ayrıca yeni araştırma sorularının ortaya çıkmasını sağlamaktadır.

- Araştırmacılar tarafından belirlenmesi güç olan soyut tutumların saptanabilmesine ve duyuşsal alana ait verilerin elde edilebilmesine katkı sağlamaktadır (Koç, 2014).

Metaforlar canl1-cansız, soyut-somut ve olumlu-olumsuz olabilmektedir. Yeterince anlaşılmamış konuların daha kolay anlaşılmasını sağlayan metaforlar bilgi toplama aracı ve sorgulama aracı da olabilmektedir (Semerci, 2007). Metafor, bireylerin yüksek düzeyde soyut, karmaşık veya kuramsal bir olguyu anlamada ve açıklamada işe koşabileceği güçlü bir zihinsel araçtır. Metaforlar iki benzeşmez olgu arasında bir ilişki kurulmasını sağlar veya belli bir zihinsel şemanın başka bir zihinsel şema üzerine yansitılmasına olanak verir. Bu durum ise metaforu, bir zihinsel araç olarak güçlü kılmaktadır. Metaforlar, bir bireyin zihninin belli bir anlayış (kavrayış) biçiminden başka bir anlayış (kavrayış) biçimine hareket etmesini sağlar. Böylece birey belli bir olguyu başka bir olgu olarak görebilir (Saban, 2008). Bireylerin kişisel tecrübelerine anlam vermeleri bakımından tecrübelerin dili olan metaforlar (Lakoff ve Johnson, 2005), problemlerin net bir şekilde ortaya konulmasında önemli rol oynayarak düşüncelerin özetlenmesini de sağlamaktadır (Semerci, 2007). Birisi hiç 
gidilmemiş bir yerin havasını anlatırken "Oranın havası çok sıcak ve nemlidir" demesiyle "İnsanın gömleği vücuduna yapışıyor, insan nefes alırken boğulacakmış gibi oluyor." demesi farklıdır. Birinci anlatım soyut bir tarif, ikincisi ise benzetmeyle (metaforla) yapılan bir anlatımdır. Tipkı ev kadınları üzerine yapılan bir araştırmada bir ev kadınının kendini tanımlamak için kullandığ1 "Kendime baktığımda aynada kocaman bir sıfır görüyorum." cümlesi metafora bir örnektir. Kadın, sayfalarca anlatılacak duygu ve düşüncesini bir cümle ile özetlemiştir. Çok güçlü bir şekilde anlatmak istediklerini, ifade etmiştir. Kadın kendisi ile ilgili, duygu ve düşüncelerini birçok sosyologun anlatamayacağ 1 kısa ve öz bir cümle ile metafor kullanarak anlatmayı başarmıştır (Aksoy, 2011).

Son yıllarda bilgi ve iletişim teknolojilerindeki hızlı değişim ve gelişme yaşanmaktadır. Bu değişim ve gelişmeye gençler, çocuklar çok hızlı uyum sağlarken, yaşlılar bu hızı yakalayamamaktadırlar. Bu sebeple yaşlı bireyler teknolojiyi bazı durumlarda sorun olarak algılanabilmektedir. $\mathrm{Bu}$ bağlamda bu çalışmanın amacl; Çocukların ve yaşlıların, bilgi ve iletişim teknolojilerine ilişkin algılarını metaforlar yoluyla belirlemektir. Çocukların ve yaşlıların, bilgi ve iletişim teknolojilerinde en çok kullanılan araçlardan olan, bilgisayar, cep telefonu ve interneti nasıl anlamlandırdıkları ve imgesel olarak nasıl ifade ettiklerini belirlemek araştırmanın temelini oluşturmaktadır. Belirlenen metaforlar değerlendirilerek yaşlıların ve çocukların bilgisayar, internet ve cep telefonuna ilişkin düşünceleri ve aralarındaki fark ortaya konmaya çalışılmıştır.

$\mathrm{Bu}$ genel amaç çerçevesinde araştırmaya ilişkin alt amaçlar şöyle sıralanmıştır:

1. Yaşlıların, BİT'e ilişkin sahip oldukları metoforlar nelerdir?

2. Yaşlıların, BİT ilişkin sahip oldukları metaforlar, hangi

kavramsal kategoriler altında toplanabilir?

3. Çocukların, BİT ilişkin sahip oldukları metoforlar nelerdir?

4. Çocukların, BİT ilişkin sahip oldukları metaforlar, hangi kavramsal kategoriler altında toplanabilir?

\section{Yöntem}

Bu araştırma, 2016 yılında Kayseri'de yaşayan, 65 yaş ve üzeri nine ve dedeler ile onların torunlarından oluşan 8 ile 12 yaşları arasındaki çocuklar 
üzerinde yürütülmüştür. Gönüllülük esasına göre belirlenen 36 yaşlı, 36 çocuk (torun), toplam: 72 birey araştırmaya dahil edilmiştir. Araştırmacıya yakın ve erişilmesi kolay olan bir durumu seçmesini sağlayan kolay ulaşılabilir durum örneklemesi, bu çalışmada örneklem seçiminde tercih edilmiştir (Yıldırım ve Şimşek, 2016). Ninelerden ve dedelerden oluşan yaşlı bireylerin ve çocukların, BiंT'lerinden en çok kullanılan, bilgisayar/tablet, internet, akıllı telefon kavramlarına yönelik metaforik algılarının belirlenmesine yönelik yapılan bu çalışma betimsel tarama modelindedir. Araştırmada nitel araştırma desenlerinden olgu bilim deseni (fenomenoloji) kullanılmıştır. Bu desende aynı olayı deneyimleyen çok sayıdaki kişi üzerinde çalışılarak kişilerin, bir olguya ilişkin algıları, bunlarla ilgili yaşantıları, olguya yükledikleri anlamlar yapılan içerik analizi ile ortaya çıkarılmaya çalışılmıştır. (Yıldırım ve Şimşek, 2016).

\section{Veri Toplama Aracı}

Araştırmanın veri toplama aracı olarak, çalışma kapsamındaki bireylerin, belirlenmiş olan kavramlara ilişkin metaforik algılarının belirlenebilmesi için, üç adet açık uçlu sorudan oluşan form kullanılmıştır. Araştırmaya katılan yaşlılardan ve çocuklardan formda yer alan cümleyi tamamlamaları istenmiştir. Formda yer alan cümleler şu şekildedir: "Bilgisayar/Tablet.............'ye/ya benzer; çünkü................."; "İnternet...................'ye/ya benzer; çünkü......................."; "Ak1llı telefonlar...............'ye/ya benzer; çünkü...................". Elde edilen bu cümleler araştırmanın veri kaynağını oluşturmaktadır.

\section{Verilerin Analizi}

Verilerin çözümlenmesinde "içerik analizi tekniği" kullanılmıştır. İçerik analizinde temel amaç, verileri belirli bir amaç bakımından sinıflandırılarak, ilişkilendirerek, çeşitli kavram ve temalar çerçevesinde bir araya getirerek yorumlamak ve verilerin açılanabileceği kavramlara ve ilişkilere ulaşmaktır. İçerik analizinde birbirine benzeyen veriler belirli kavramlar ve temalar çerçevesinde bir araya getirilerek anlaşılır biçimde düzenlenmektedir (Yıldırım ve Şimşek, 2016). 
Çözümleme işlemi 4 uzmandan oluşan grup tarafından yapılmıştır. İlk aşamada yaşlıların ve çocukların oluşturdukları metaforlar araştırmacılar tarafından incelenmiş; birden fazla metaphor üreten, kullanılan metaphor ile açıklama cümlesi uyuşmayan, hepsi cevaplanmayan formlar çalışmadan çıkarılmıştır ve geriye kalan formlar numaralandırılarak listelenmiştir. İkinci aşamada; ortaya çıkan metaforlar listelenmiştir. Bu listeleme sırasında üretilen metaforların benzer özellikte olanları (metafora konu ve atfedilen düşünce) gruplandırılmıştır. Üçüncü aşamada ise; gerekçelerde incelenerek metaforlar katogorilere ayrılmıştır. Bu katogoriler niniler, dedeler ve çocuklara göre tablolaştırılmıştır.

\section{Bulgular}

Ninelerden ve dedelerden oluşan yaşlı bireyler ile çocukların bilgisayar/tablet, internet ve akıllı telefon kavramlarına yönelik metaforik algılarının belirlenmesine yönelik toplanan veriler analiz edilerek altı tablo oluşturulmuştur. Tablolar, analiz sonucunda ortaya çıkan metaforları, metaforların benzetme yönlerini ve metaforların toplandığı ortak kategori bölümlerini içermektedir. Metaforlar ve kategorilerine ilişkin açıklamalar aşağıda yer almaktadır.

Tablo 1. Ninelerin ve Dedelerin Bilgisayara İlişkin Metaforları, Gerekçeleri ve Kategoriler

\begin{tabular}{lllll}
\hline Sıra & Metafor & $\mathbf{f}$ & Benzetme Yönü & Kategori \\
\hline 1 & Televizyon & 12 & Görsel Özellikleri & \\
2 & Kutu & 7 & Şekil & Biçimsel ve İşlevsel \\
3 & Kara kutu & 1 & Zağlığa zararlı, zarar verme & \\
\hline 4 & Çöp kutusu & 4 & Kullanılmıyor & Gereksiz \\
\hline 5 & Eğlence & 3 & Film izleme & Oyun \\
\hline 6 & Kitap & 2 & Bilgiye ulaşma & Erişim \\
7 & Dünyayı küçülten nesne & 2 & İşlevselliği & Bağımlılık \\
\hline 8 & Hapishane & 1 & Herkesi İçine hapseder & Hayatı kolaylaştırma \\
9 & Yokluk & 1 & Zaman kaybı & Yönetme \\
\hline 10 & Nesne & 1 & İyi bir gereç & Zaman kaybı \\
\hline 11 & Araba & 1 & Bireysel kullanım & \\
\hline 12 & Ömür & 1 & Hizı & \\
\hline
\end{tabular}

Tablo 1 incelendiğinde, 36 yaşlının, 12 metafor geliştirdiği görülmektedir. Yaşlıların bilgisayara ilişkin olarak geliştirdikleri metaforlar gerekçeleri 
dikkate alınarak sekiz grupta kategorize edilmiştir. Yaşlıların geliştirdikleri metaforlar incelendiğinde "Biçimsel ve İşlevsel", "Gereksiz", "Oyun", "Erişim", "Bağımlılık", "Hayatı kolaylaştırma", "Yönetme" ve "Zaman kaybı" yönlerine vurgu yaptıkları görülmektedir. Bu doğrultuda yapılan yorumlardan bazılarına aşağıda yer verilmiştir.

\section{Biçimsel ve İşlevsel}

Yaşlıların bu gruba ilişkin olarak geliştirdikleri metaforlar, "televizyon", "kutu", şeklindedir. Buna göre, ortaya çıan metaforların bilgisayara ilişkin görsel özellikler ve şekil yönüne vurgu yaptıkları görülmektedir. Bu grupta en fazla vurgu yapılan metafor "televizyon" metaforudur. Yaşlıların, bilgisayarın biçimsel ve işlevsel boyutu ile ilgili olarak geliştirdikleri metaforlara ilişkin yorumlar aşağıda yer almaktadır.

Bilgisayarı "televizyona" benzeten yaşlı "Bilgisayarda televizyon gibi haberleri, bazı bilgileri, dizileri gösteriyor, her şeyi orada görüyoruz" sözleri ile benzetme gerekçesini açıklamıştır.

Bilgisayarı "kutuya" benzeten yaşlı "dört köşe bir kutuya benzer, kutuya da işe yaramayan, kullanilmayan her şeyi koyarız, bilgisayarda da işe yaramayan bir sürü bilgi saklarız" sözleri ile benzetme gerekçesini açıklamıştır.

\section{Gereksiz}

Yaşlıların bu gruba ilişkin olarak geliştirdikleri metafor, "çöp kutusu", şeklindedir. Yaşlıların, bilgisayarın gereksiz boyutu ile ilgili olarak geliştirdikleri metaforlara ilişkin yorum aşağıda yer almaktadır.

Bilgisayarı "Çöp kutusuna" benzeten yaşlı "Benim için çok anlam ifade etmiyor, kullanılmayan her şeyi çöpe attığım için, bilgisayarda kullanılmayan bir çok şeyin atıldı̆̆ı çöp kutusu gibidir" sözleri ile benzetme gerekçesini açıklamıştır. 


\section{Bağımlılık}

Yaşlıların bu gruba ilişkin olarak geliştirdikleri metafor, "Hapishane", "Yokluk" şeklindedir. Yaşlıların, bilgisayarın bağımlılık boyutu ile ilgili olarak geliştirdikleri metaforlara ilişkin yorumlar aşağıda yer almaktadır.

Bilgisayarı "hapishaneye" benzeten yaşlı "Büyük küçük herkesi içine çekiyor, saatlerce kendisine mahkum ediyor, fakat insanlar mahkum olduklarmın farkına bile varmıyorlar. Suç işlemeden kendilerini habis ediyorlar" sözleri ile benzetme gerekçesini açıklamıştır.

Tablo 2. Ninelerin ve Dedelerin İnternete İlişkin Metaforları, Gerekçeleri ve Kategoriler

\begin{tabular}{lllll}
\hline Sıra & Metafor & f & Benzetme Yönü & Kategori \\
\hline 1 & Balık Ağı & 1 & Etki altına alma & \\
2 & Oyun Tuzağı & 9 & Olumsuz etkilemesi & Bağımlılık \\
3 & Kahvehane & 3 & Kendini kaptırma & \\
4 & Sigara & 7 & Bağımlılık yapması & İşlevsellik \\
\hline 5 & Televizyon & 2 & Haber izleyebilme & \\
\hline 6 & Uzay & 3 & Sonsuz bilgi & Bilgi Erişimi \\
7 & Ansiklopedi & 2 & İstenilen bilgiye ulaşma & \\
8 & Güvercin & 2 & Anında bilgiye ulaşma & \\
9 & Hayalet & 1 & Her an her yerden erişim & İetişim \\
10 & Muhtar & 1 & Her şeyden haberdar olma & \\
11 & Soru Makinesi & 1 & Anında dönüt & \\
\hline 12 & Akraba & 3 & Mesafeyi kısaltma & \\
13 & Ulaşım & 1 & Uzakları yakın etme & \\
\hline
\end{tabular}

Tablo 2 incelendiğinde, 36 yaşlının, 13 metafor geliştirdiği görülmektedir. Yaşlıların internete ilişkin olarak geliştirdikleri metaforlar gerekçeleri dikkate alınarak dört grupta kategorize edilmiştir. Yaşlıların geliştirdikleri metaforlar incelendiğinde "Bağımlılık", "İşlevsellik", "Bilgi erişimi” ve "İletişim", yönlerine vurgu yaptıkları görülmektedir. Bu doğrultuda yapılan yorumlara aşağıda yer verilmiştir.

\section{Bağımlılık}

Yaşlıların bu gruba ilişkin olarak geliştirdikleri metafor, "Balık ağı", "Oyun tuzağı", "Kahve hane", "Sigara" şeklindedir. Buna göre, ortaya 
çıkan metaforların internetin bağımlılık yönüne vurgu yaptığ görülmektedir. Bu grupta en fazla vurgu yapılan metafor "oyun tuzağıdır", ikinci sırada "sigara" metaforu vardır. Yaşlıların, internetin bağımlılık boyutu ile ilgili olarak geliştirdikleri metaforlara ilişkin yorumlar aşağıda yer almaktadır.

İnterneti, "balık ağına" benzeten yaşlı "Bütün insanları sarıyor, şimdiki devir onsuz duramıyor, ağlara takılmıs balıklar gibi sürekli internet arıyorlar. Balıklar ağda insanlar internette çırpınıyor" sözleri ile benzetme gerekçesini açıklamıştır.

\section{Bilgi Erişimi}

Yaşlıların bu gruba ilişkin olarak geliştirdikleri metafor, "Uzay", "Ansiklopedi", "Güvercin", "Hayalet" ve "Muhtar" şeklindedir. Buna göre, ortaya çıkan metaforların internetin bilgi erişimi yönüne vurgu yaptığ1 görülmektedir. Bu grupta en fazla vurgu yapılan metafor "uzay", metaforudur. Yaşlıların, internetin bilgi erişimi boyutu ile ilgili olarak geliştirdikleri metaforlara ilişkin yorumlar aşağıda yer almaktadır

İnterneti, "Muhtara" benzeten yaşl1 "her şeyden haberi var" sözleri ile benzetme gerekçesini açıklamıştır.

Tablo 3. Ninelerin ve Dedelerin Akıllı Telefonlara İlişkin Metaforları, Gerekçeleri ve Kategoriler

\begin{tabular}{lllll}
\hline Sıra & Metafor & f & Benzetme Yönü & Kategori \\
\hline 1 & Beyin & 7 & Çok yönlülük & \multirow{2}{*}{ Depolama } \\
2 & Ansiklopedi & 5 & Bilgi saklama & \\
\hline 3 & Kumanda & 1 & Tuşlara sahip olması & \\
4 & Asistan & 1 & Yardım etme & İşlevsellik/ \\
5 & Küçük telefon & 1 & Biçimsel özellikler & fonsiyonellik \\
6 & Gazete & 2 & Haberlere erişebilme & \\
\hline 7 & Tembellik & 3 & Zaman öldürme & \\
8 & Oyuncak & 4 & Sürekli kullanım & \multirow{2}{*}{ Bağımlılık } \\
9 & Gölge & 4 & Uzva dönüşmesi & \\
10 & Sağ kol & 1 & Vazgeçememe & \\
\hline 11 & Zincire & 1 & Esir etmek & Özgürlük Sınırlaması \\
\hline 12 & Arkadaş & 5 & Vakit geçirme & İletişim \\
\hline 13 & Su & 1 & Vazgeçilememezlik & Hayati İhtiyaç \\
\hline
\end{tabular}


Tablo 3 incelendiğinde, 36 yaşlının, 13 metafor geliştirdiği görülmektedir. Yaşlıların akıllı telefona ilişkin olarak geliştirdikleri metaforlar, gerekçeleri dikkate alınarak altı grupta kategorize edilmiştir. Yaşlıların geliştirdikleri metaforlar incelendiğinde "Depolama", "İşlevsellik/fonksiyonellik", "Bağımlılık ", “Özgürlük sinırlaması”, "İletişim” ve "Hayati ihtiyaç", yönlerine vurgu yaptıkları görülmektedir. Bu doğrultuda yapılan yorumlara aşağıda yer verilmiştir.

\section{Depolama}

Yaşlıların bu gruba ilişkin olarak geliştirdikleri metafor, "Beyin", "Ansiklopedi", şeklindedir. Buna göre, ortaya çıkan metaforların akıllı cep telefonunun depolama yönüne vurgu yaptığ1 görülmektedir. Bu grupta en fazla vurgu yapılan metafor "Beyin", metaforudur. Yaşlıların, bilgi erişimi boyutu ile ilgili olarak geliştirdikleri metaforlara ilişkin yorumlar aşağıda yer almaktadır

Akıllı cep telefonunu, "Beyne" benzeten yaşlı "Bizim yerimize her şeyi saklyyor, unutmuyor resimleri saklyyor bakınca anıları hatırlıyorsun" sözleri ile benzetme gerekçesini açıklamıştır.

Akıllı cep telefonunu, "ansiklopediye" benzeten yaşlı "Aklımızda tutamadı̆̆ımı bilgileri tarih ve saat detayına kadar saklıyor, randevularımızı," resimlerimizi saklıyor " sözleri ile benzetme gerekçesini açıklamıştır.

\section{Hayati İhtiyaç}

Yaşlıların bu gruba ilişkin olarak geliştirdikleri metafor, "su", şeklindedir. Buna göre, ortaya çıkan metaforun akıllı cep telefonunun hayati ihtiyaç yönüne vurgu yaptığı görülmektedir. Yaşlıların, hayati ihtiyaç boyutu ile ilgili olarak geliştirdikleri metafora ilişkin yorum aşağıda yer almaktadır.

Akıllı cep telefonunu, "suya" benzeten yaşlı "herkes tarafindan kullanılan, nasıl su olmadan insanlar çok az dayanırsa telefon olmadan da o kadar az dayanıyorlar" sözleri ile benzetme gerekçesini açıklamıştır. 
Tablo 4. Torunların Bilgisayara İlişkin Metaforları, Gerekçeleri ve Kategoriler

\begin{tabular}{lllll}
\hline Sıra & Metafor & f & Benzetme Yönü & Kategori \\
\hline 1 & Telefona & 3 & İşlevselliği & \multirow{2}{*}{ Biçimsellik } \\
2 & Dikdörtgen & 1 & Şekil özelliği & \\
\hline 3 & Roket & 1 & Hız & \\
4 & Uzay aracı & 1 & Her yere erişim & Fonksiyonellik \\
5 & Dünya & 1 & Her şeyi barındırması & \\
6 & Einstein & 1 & Zeka & \\
7 & Otobüs & 1 & Hız ve erişim & Depolama \\
\hline 8 & Kütüphane & 2 & Bilgi çeşitliliği & Bağımlılık \\
9 & Sır kutusu & 1 & Her şeyi saklama & Eğlence \\
\hline 10 & Oyun & 1 & Sürekli isteme & \\
\hline 11 & Oyuncak & 5 & Oynama fırsatı & \\
12 & Gökkuşağ & 1 & Keyif verici & \\
\hline
\end{tabular}

Tablo 4 incelendiğinde, 36 çocuğun, 12 metafor geliştirdiğ $i$ görülmektedir. Çocukların bilgisayara ilişkin olarak geliştirdikleri metaforlar, gerekçeleri dikkate alınarak beş grupta kategorize edilmiştir. Çocukların geliştirdikleri metaforlar incelendiğinde "Biçimsellik", "Fonksiyonellik", "Depolama”, "Bağımlılık" ve "Eğlence", yönlerine vurgu yaptıkları görülmektedir. Bu doğrultuda yapılan bazı yorumlara aşağıda yer verilmiştir.

\section{Foksiyonellik}

Çocukların, bu gruba ilişkin olarak geliştirdikleri metafor, "Roket”, "Uzay aracı", "Dünya", "Einstein" ve “Otobüs" şeklindedir. Buna göre, ortaya çıkan metaforların bilgisayarın fonksiyonellik yönüne vurgu yaptığ1 görülmektedir. Çocukların, fonksiyonellik boyutu ile ilgili olarak geliştirdikleri metaforlara ilişkin yorumlar aşağıda yer almaktadır

Bilgisayarı, "Einstein" benzeten çocuk "onun kadar akıll, her şeyi biliyor, buluyor" sözleri ile benzetme gerekçesini açklamıştır.

Bilgisayarı, "uzay aracına" benzeten çocuk "onunla her şeyi yapabilirsin, her yere gidebilirsin" sözleri ile benzetme gerekçesini açıklamıştır. 


\section{Eğlence}

Çocukların, bu gruba ilişkin olarak geliştirdikleri metafor, "Oyuncak", "Gök kuşağı", şeklindedir. Buna göre, ortaya çıan metaforların bilgisayarın eğlence yönüne vurgu yaptı̆̆ görülmektedir. Bu grupta en fazla vurgu yapılan metafor "Oyuncak", metaforudur. Çocukların, eğlence boyutu ile ilgili olarak geliştirdikleri metaforlara ilişkin yorumlar aşağıda yer almaktadır.

Bilgisayarı, "oyuncağa" benzeten çocuk "hep oyun oynayabiliyorsun" sözleri ile benzetme gerekçesini açıklamıştır.

Bilgisayarı, "gökkuşağına" benzeten çocuk "beni mutlu ediyor" sözleri ile benzetme gerekçesini açıklamıştır.

Tablo 5. Torunların İnternete İlişkin Metaforları, Gerekçeleri ve Kategoriler

\begin{tabular}{lllll}
\hline Sıra & Metafor & f & Benzetme Yönü & Kategori \\
\hline 1 & Kitap & 7 & Bilgi çeşitliliği & \\
2 & Beyin & 5 & Fonksiyonellik & \\
3 & Öğretmen & 1 & Bilmediğimizi öğretme & Bilgi erişimi \\
4 & Sözlük & 2 & Bilgileri Bulabilme & \\
5 & Bilim adamı & 1 & Her şeyi bilme & \\
\hline 6 & Modem & 1 & Görsellik & \multirow{2}{*}{ Somutlaştırma } \\
7 & Görünmez ip & 1 & İlevsellik & \\
8 & Sinek & 1 & Hiz & \\
9 & Çanak anten & 1 & Erişim & Erişim \\
10 & Deniz & 1 & Uçsuz bucaksız olması & \\
\hline 11 & Koşucu & 1 & Hiz & Eğlence \\
12 & Uçak & 1 & Ulaşım & Bağımlılık \\
13 & Dünya & 2 & Uzakları yakınlaştırma & \multirow{2}{*}{ Evrensellik } \\
\hline 14 & Oyuncak & 6 & Vakit geçirme & \\
\hline 15 & Örümcek ağı & 1 & Tutsak etme & \\
\hline 16 & Dünya & 2 & Herkes tarafından kullanılması & \\
17 & Olağanüstü bir şey & 2 & Herkesle bağlantı sağlama & \\
\hline
\end{tabular}

Tablo 5 incelendiğinde, 36 çocuğun, 17 metafor geliştirdiği görülmektedir. Çocukların internete ilişkin olarak geliştirdikleri metaforlar, gerekçeleri dikkate alınarak altı grupta kategorize edilmiştir. Çocukların geliştirdikleri metaforlar incelendiğinde "Bilgi erişimi", 
"Somutlaştırma", "Erişim", "Eğlence", "Bağımlılık" ve "Evrensellik", yönlerine vurgu yaptıkları görülmektedir. $\mathrm{Bu}$ doğrultuda yapılan yorumlara aşağıda yer verilmiştir.

\section{Bilgi erişimi}

Çocukların, bu gruba ilişkin olarak geliştirdikleri metaforlar, "Kitap", "Beyin”, “Öğretmen”, “Sözlük” ve "Bilim adamı” şeklindedir. Buna göre, ortaya çıan metaforların internetin bilgi erişimi yönüne vurgu yaptığ1 görülmektedir. Bu grupta en fazla vurgu yapılan metafor "Kitap", daha sonra ise "Beyin" metaforu vardır. Çocukların, internetin bilgi erişimi boyutu ile ilgili olarak geliştirdikleri metaforlara ilişkin yorumlar aşağıda yer almaktadır.

İnterneti, "Kitaba" benzeten çocuklar "her ikisi de bilgi veriyor", "her sorunun cevabı vardır" sözleri ile benzetme gerekçesini açıklamışlardır.

İnterneti, "Bilim adamına" benzeten çocuk "ne sorsak cevap veriyor" sözleri ile benzetme gerekçesini açıklamıştır.

\section{Somutlaştırma}

Çocukların, bu gruba ilişkin olarak geliştirdikleri metaforlar, "Modem", "Görünmez ip", "Sinek", "Çanak anten" ve "Deniz" şeklindedir. Buna göre, ortaya çıkan metaforla ile çocukların soyut bir kavramı somut bir kavramla açıladıkları görülmektedir. Çocukların, internetin somutlaştırma boyutu ile ilgili olarak geliştirdikleri metaforlara ilişkin yorumlar aşağıda yer almaktadır.

İnterneti, “Görünmez ipe" benzeten çocuk "bir çok ipin birbirine bağlanması, bir iple bağ lı" sözleri ile benzetme gerekçesini açıklamıştır.

İnterneti, "Sineğe" benzeten çocuk "Her yere girip çıkıyor" sözleri ile benzetme gerekçesini açıklamıştır.

Tablo 6 incelendiğinde, 36 çocuğun, 15 metafor geliştirdiğ $i$ görülmektedir. Çocukların akıllı telefona ilişkin olarak geliştirdikleri metaforlar, gerekçeleri dikkate alınarak altı grupta kategorize edilmiştir. Çocukların geliştirdikleri metaforlar incelendiğinde "Fonksiyonellik", "Somutlaştırma", “İletişim", "Eğlence", "Depolama" ve "Bağımlılık" , 
yönlerine vurgu yaptıkları görülmektedir. Bu doğrultuda yapılan yorumlara aşağıda yer verilmiştir.

Tablo 6. Torunların Akıllı Telefona İlişkin Metaforları, Gerekçeleri ve Kategoriler

\begin{tabular}{|c|c|c|c|c|}
\hline Sira & Metafor & $\mathbf{f}$ & Benzetme Yönü & Kategori \\
\hline 1 & Tablet & 5 & İşlevsellik & \multirow{2}{*}{ Fonksiyonellik } \\
\hline 2 & Beyin & 3 & Çok yönlülük & \\
\hline 3 & Baston & 1 & Erişim kolaylığg & \multirow{5}{*}{ Somutlaştırma } \\
\hline 4 & Gökyüzü & 1 & Uçsuz bucaksız olması & \\
\hline 5 & Yardımcı & 2 & Yönlendirme & \\
\hline 6 & Canavar & 1 & Her şeye yetişebilme & \\
\hline 7 & Steiven Jobs & 1 & Yaratıcilık ve keşfetme & \\
\hline 8 & Haberleşme & 6 & Diyalog kurma & \multirow{4}{*}{ İletişim } \\
\hline 9 & Kavuşma & 1 & Bir araya getirme & \\
\hline 10 & Kuş & 1 & Her yere erişim & \\
\hline 11 & Telsiz & 4 & Konuşabilme özelliği & \\
\hline 12 & Şeker & 1 & Mutluluk verici & \multirow[t]{2}{*}{ Eğlence } \\
\hline 13 & Oyun & 6 & Vakit geçirme & \\
\hline 14 & Küçük obje & 2 & Her şeyi içinde barındırabilme & Depolama \\
\hline 15 & Çikolata & 1 & Vazgeçilmezlik & Bağımlılık \\
\hline
\end{tabular}

\section{İletişim}

Çocukların, bu gruba ilişkin olarak geliştirdikleri metaforlar, "Haberleşme”, "Kavuşma", "Kuş", “Telsiz” şeklindedir. Buna göre, ortaya çıkan metaforların akıllı telefonun iletişim yönüne vurgu yaptığı görülmektedir. Bu grupta en fazla vurgu yapılan metafor "Haberleşme", daha sonra ise "Telsiz" metaforudur. Çocukların, akıllı telefonun iletişim boyutu ile ilgili olarak geliştirdikleri metaforlara ilişkin yorumlar aşağıda yer almaktadir.

Akıllı telefonu, "Haberleşme" benzeten çocuk "uzakta olan akrabalarımızla görüntülü konuşuruz, inanlar birbirleri ile konuşurlar" sözleri ile benzetme gerekçesini açıklamıştır.

Akıllı telefonu, "Telsize" benzeten çocuk "herkesle elinde konuşursun" sözleri ile benzetme gerekçesini açılamıştır. 


\section{Bağımlılık}

Çocukların, bu gruba ilişkin olarak geliştirdikleri metafor, "Çikolata", şeklindedir. Buna göre, ortaya çıan metaforun akıllı telefonun bagımlılık yönüne vurgu yaptığı görülmektedir. Çocukların, akıllı telefonun bagımlılık boyutu ile ilgili olarak geliştirdikleri metafora ilişkin yorumlar aşağıda yer almaktadır.

Akıllı telefonu, "Çikolataya" benzeten çocuk "Şekil olarak benzer, tat olanakta benzer çok lezzetli ve asla vazgeçmem sürekli isterim" sözleri ile benzetme gerekçesini açıklamıştır.

\section{Sonuç}

Araştırma sonucunda, nineler ve dedelerden oluşan yaşlıların bilgisayara yönelik olarak geliştirdikleri metaforlar sekiz kategoride toplanmıştır. Bunlar; "Biçimsel ve İşlevsel", "Gereksiz", "Oyun", "Erişim", "Bağımlılık", "Hayatı kolaylaştırma”, "Yönetme" ve "Zaman kaybı" olarak belirlenmiştir. Bilgisayarın biçimsel ve işlevsel kategorisini ifade eden metaforlar "televizyon", "kutu”, "kara kutu” şeklinde siralanmaktadır. Gereksiz boyutuna ilişkin metafor, "çöp kutusu", oyun boyutuna ilişkin metafor ise, "eğlence", erişim boyutuna ilişkin metaforlar ise, "kitap" ve "dünyayı küçülten nesne", bağımlılık boyutuna ilişkin metaforlar ise, "hapishane" ve "yokluk" şeklinde sıralanmaktadır.

Nineler ve dedelerden oluşan yaşlıların internete yönelik olarak geliştirdikleri metaforlar dört kategoride toplanmıştır. Bunlar; "Bağımlılık", "İşlevsellik", "Bilgi erişimi”, "İletişim", olarak belirlenmiştir. İnternetin bağımlılık kategorisini ifade eden metaforlar "Balık ağı", "Oyun tuzağ 1 ”, "Kahvehane" ve "Sigara" şeklinde sıralanmaktadır. İşlevsellik boyutuna ilişkin metafor, "Televizyon"; iletişim boyutuna ilişkin metaforlar ise, "Akraba" ve "Ulaşım" şeklinde sıralanmaktadır.

Nineler ve dedelerden oluşan yaşlıların akıllı telefona yönelik olarak geliştirdikleri metaforlar altı kategoride toplanmıştır. Bunlar; "İşlevsellik ve fonksiyonellik", "Bağımlılık", "Özgürlük sınırlaması", "İletişim”, "Hayati ihtiyaç" olarak belirlenmiştir. Akıllı telefonun işlevsellik/ fonksiyonellik kategorisini ifade eden metaforlar "Kumanda", "Asistan”, “Küçük 
telefon" ve "Gazete" şeklinde sıralanmaktadır. Bağımlılık boyutuna ilişkin metaforlar ise, "Tembellik", "Oyuncak", "Gölge", "Sağ kol"; özgürlük sınırlaması boyutuna ilişkin metafor ise, "Zincir"; İletişim boyutuna ilişkin metafor ise, "Arkadaş"; Hayati ihtiyaç boyutuna ilişkin metafor ise "Su" şeklinde sıralanmaktadır.

Araştırma sonucunda, torunlardan oluşan çocukların bilgisayara yönelik olarak geliştirdikleri metaforlar beş kategoride toplanmıştır. Bunlar; "Biçimsellik", "Fonksiyonellik", "Depolama", "Bağımlılık" ve "Eğlence" olarak belirlenmiştir. Bilgisayarın biçimsellik kategorisini ifade eden metaforlar "telefon" ve "dikdörtgen" ; Fonksiyonellik boyutuna ilişkin metafor, "roket", "uzay arac1", "Dünya", " Eistein" ve "Otobüs" iken; Depolama boyutuna ilişkin metafor ise, "Kütüphane" ev "Sır kutusu"; bağımlılık boyutuna ilişkin metafor ise, "Oyun"; eğlence boyutuna ilişkin metaforlar ise, "oyuncak" ve "gökkuşağı" şeklinde sıralanmaktadır.

Çocukların internete yönelik olarak geliştirdikleri metaforlar altı kategoride toplanmıştır. Bunlar; "Bilgi erişimi", "Somutlaştırma", "Erişim", "Eğlence", "Bağımlılı" ve "Evrensellik" olarak belirlenmiştir. İnternetin bilgi erişimi kategorisini ifade eden metaforlar "kitap", "beyin”, "Öğretmen", "Sözlük" ve "Bilim adamı" iken; somutlaştırma boyutuna ilişkin metaforlar, "Modem", "Görünmez ip", "Sinek", " Çanak anten" ve "Deniz" iken; Erişim boyutuna ilişkin metafor ise, "Koşucu" "Uçak" ve "Dünya"; eğlence boyutuna ilişkin metafor ise, "Oyuncak"; Bağımlılık boyutuna ilişkin metafor ise, "Örümcek ağı"; Evrensellik boyutuna ilişkin metaforlar, "Dünya" ve "Olağan üstü bir şey" şeklinde sıralanmaktadır.

Çocukların akıllı telefona yönelik olarak geliştirdikleri metaforlar altı kategoride toplanmıştır. Bunlar; "Fonksiyonellik", "Somutlaştırma", "İletişim", "Eğlence", "Depolama" ve "Bağımlılık" olarak belirlenmiştir. Ak1llı telefonun fonksiyonellik kategorisini ifade eden metaforlar "Tablet", "Beyin"; somutlaştırma boyutuna ilişkin metaforlar, "Baston", "Gökyüzü", "Yardımcı", “Canavar" ve "Steiven Jobs"; İletişim boyutuna ilişkin metafor ise, "Haberleşme" "Kavuşma" ve "Kuş" ve "Telsiz"; eğlence boyutuna ilişkin metafor ise, "Şeker" ve "Oyun"; Depolama boyutuna ilişkin metafor, "Küçük obje"; Bağımlılık boyutuna ilişkin metafor ise, "Çikolata"; şeklinde belirlenmiştir.

Yaşlıların BİT'e ilişkin geliştirdikleri metaforlar incelendiğinde; genellikle olumsuzluk içeren metaforlar oldukları görülmektedir. Özellikle 
bağımlılık boyutundaki metaforlar incelendiğinde olumsuz ve negatif özellikler taşıyan (balık ağı, sigara, tuzak, hapishane) metaforlar kullandıkları görülmektedir. Bu durum yaşlıların BİT'e hızlı ilerleyişe ve değişime ayak uyduramamalarından kaynaklı olumsuz duyguların yansıması olarak düşünülebilir.

Çocukların BİT ilişkin geliştirdikleri metaforlar incelendiğinde; bu metaforların genellikle olumluluk içeren metaforlar oldukları görülmektedir. Bağımlılık boyutundaki metoforlar bile olumluluk içeren ve çocuklar tarafından sevilen (Çikolata, oyun) nesne ve faaliyetlerdir. Çocuklar bağımlılık boyutlarında bir veya iki metafor oluştururken; yaşlılar; bilgisayar, internet ve akıllı telefon için frekansları fazla olan en az dörder adet metafor oluşturmuşlardır. Çocukların metaforlarında rastlanan diğer bir özellik ise bilgisayar, akıllı telefon ve özelliklede interneti anlatırken somut özellikler kullanarak metafor oluşturdukları (uzay aracı, dünya, görünmez ip, çanak anten, Eistein) görülmektedir. Piagete göre çocukların bilişsel gelişimi yaşlara göre dört dönemde gerçekleşir: 0-2 yaş duyu motor dönem, 2-7 yaş işlem öncesi dönem, 7-11 yaş somut işlemler dönemi ve 11 yaş ve üzeri soyut işlemler dönemidir (İnanç, Bilgin ve Kılıç, 2007). Bu çocukların soyut kavramları bilişsel gelişim düzeylerine uygun olarak somut kavramlarla açılama özelliklerinden kaynaklanmaktadırlar. Çocuklar BİT’lere yaşlıların aksine daha olumlu yaklaşmakta ve aktif olarak kullanmaktadırlar bu durum oluşturdukları metaforlara da yansımaktadır. Bu sonuçlar ışığında; yaşlılara ve çocuklara dönük bu araştırma yetişkinlere dönük olarak da yapılabilir.

\section{KAYNAKÇA}

Akbaş, A. (2008). Kişilik, Sosyal, Duygusal ve Ahlak Gelişimi. (Ed: K. Ersanlı ve E. Uzman) Eğitim Psikolojisi, 2. Bask1, ss: 91-144. İstanbul: Lisans Yayincilik.

Akgül, H., (2016).Yalnızlığı Azaltma Psiko-Eğitim Programının Yaşlıların Yalnızlık Düzeyine Etkisi. Yayınlanmamış Doktora Tezi, Ankara Üniversitesi, Eğitim Bilimleri Enstitüsü, Ankara.

Aksaray, S. (2011). "Siber Zorbalık”, Ç.Ü. Sosyal Bilimler Enstitüsü Dergisi, $20(2), 405-432$. 
Aksoy, T. (31 Temmuz 2011). temelaksoy.com. 02.06.2017, http://www.temelaksoy.com/metafor-yapmak-sihir-yapmakgibidir

Anderson, R. E. (2008). Implications of the Information and Knowledge Society for Education. Voogt, J., Knezek, G. (Eds.), International Handbook of Information Technology in Primary and Secondary Education (p. 5-22). New York: Springer Science Business Media LLC.

Arslan, M.M. , Bayrakçı, M. (2006). “Metaforik Düşünme ve Öğrenme Yaklaşımının Eğitim-Öğretim Açısından İncelenmesi". Milli Ĕ̆itim Dergisi, 171, 100-103.

Aydın, İ. S. ve Pehlivan, A. (2010). “Türkçe Öğretmeni Adaylarının "Öğretmen" ve "Öğrenci" Kavramlarına İlişkin Kullandıkları Metaforlar". Turkish Studies, 5(3), 818-842.

Cerit, Y. (2008). “Öğretmen Kavramı ile İlgili Metaforlara İlişkin Öğrenci, Öğretmen ve Yöneticilerin Görüşleri". Türk Eğitim Bilimleri Dergisi, 6(4), 694-712.

Dereobalı, N. (2010). Okul Öncesi Eğitim ve Kitle İletişim Araçları. (Ed: G. Haktanır). Okul Öncesi Ĕ̆itime Giriş, 4. Baskı, 263-288. Ankara: Anı Yayıncilik.

Doğan, Y. (2015). “100. Yılında Öğretmen Adayları Ve Öğrencilerin Bak1şıyla Çanakkale Savaşları: Bir Metafor Araştırması". Turkish Studies, 10(3), 369-386.

Dönmez, Y., (2012). “Yaşlılarda Teknoloji Kullanım Düzeyi Üzerine Bir İnceleme "Eskişehir İli Örneği”, Türkiye Bilimsel ve Teknolojik Araştırma Kurumu, Bursa.

http://mebk12.meb.gov.tr/meb iys dosyalar/26/14/967997/dosyalar/2012 12/10040955 28.pdf (Erişim Tarihi: 22.10.2016)

Ekici, S.K. ve Gümüş, Ö. (2016). "Yaşlılıkta teknolojinin kullanımı”. Ege Tip Dergisi, 55 (Ek Sayı / Supplement), 26-30.

Eraslan, L., (2011), "Sosyolojik Metaforlar", Akademik Bakış, 27, 1-22. Erişim Tarihi (21.10.2016) http://www.akademikbakis.org Eyidoğan, B. (2009). Bilişim Teknolojileri Dersinin Illköğretimde Seçmeli Ders Olmasına İlişkin Öğretmen Görüşleri. Yayınlanmamış Yüksek Lisans Tezi, Anadolu Üniversitesi Eğitim Bilimleri Enstitüsü, Eskişehir.

Haugen, K. (1998). “Using Technology To Enhance Early Learning Experiences". Child Care Information and Exchange, 9, 47-56. 
İnanç, B.Y., Bilgin, M. ve Kılıç Altıcı M. (2007). Gelişim Psikolojisi, Çocuk ve Ergen Gelişimi (2.Baskl). Ankara: Pegem A Yayıncllık.

Jankowska, M. A. (2004). “Identifying University Professors' İnformation Needs İn Thechallenging Environment Of İnformation And Communication Technologies". The Journal of Academic Librarianship, 30(1), 51-66.

Koç, E.S., (2014). “Sınıf Öğretmeni Adaylarının Öğretmen ve Öğretmenlik Mesleği Kavramlarına İlişkin Metaforik Algıları", İnönü Üniversitesi Ĕ̆itim Fakültesi Dergisi, 5(1), 47-72.

Lakoff, G. ve Johnson, M. (2005). Metaforlar: Hayat, Anlam ve Dil (Çev: G.Y. Demir), İstanbul: $\quad$ Paradigma Yayıncilik.

Levine, P.M. (2005). Metaphors and Images of Classrooms. ERIC: EJ724893.

Miller, D. and Slater, D. (2001). The Internet: An Ethnographic Approach. Oxford: Oxford International Publishers Ltd.

Morgan, G. (1980). Paradigms, metaphors, and puzzle solving in organizational analysis. Administrative Science Quarterly, 25, 606-622.

Özkan, Y. Ve Purutçuoğlu, E. (2010). "Yaşlılıkta Teknolojik Yeniliklerin Kabulünü Etkileyen Sosyalizasyon Süreci". Aile ve Toplum, 11(6).

Öztürk, S.A. ve Özata F.Z. (2012). Yaşlı Tüketiciler ve Teknoloji: Yaşlı Tüketicilerin Bilgi ve İletişim Teknolojileriyle İlişkilerini Anlamaya

Yönelik Nitel Bir Araştırma. Tüketici Yazıları III, Hacettepe Üniversitesi Tüketici - Pazar - Araştırma - Danışma Test ve Eğitim Merkezi (TÜPADEM) yayınları içinde bölüm: 88-109.

Resnick, M., Martin, F., Berg, R., Borovoy, R., Colella, V., Kramer, K. and Silverman, B. (1998). Digital manipulatives: new toys to think with. Proceedings of CHI'98 (ACM conference on Human Factors in Computing Systems), pp. 281-287. New York: ACM.

Rouse, M. (2005). ICT( information and communication technology-or technologies) http://searchcio- midmarket.techtarget.com/definition/ICT adresinden (Erişim Tarihi: 5.10.2016).

Semerci, Ç. (2007). Program Geliştirme Kavramına İlişkin Metaforlarla Yeni İlköğretim Programlarına Farklı Bir Bakış.Cumhuriyet Üniversitesi Sosyal Bilimler Dergisi,31 (2), 125-140.

Saban, A., (2008). “Okula İlişkin Metaforlar”. Kuram ve Uygulamada Eğitim Yönetimi Dergisi, 55, 459-496. 
Siraj-Blatchford, I. and Siraj-Blatchford, J. (2003). More than Computers: Information and Communication Technology in the Early Years. London: The British Association for Early Childhood Education.

Türkiye İstatistik Kurumu, (2015). Hane Halkı Bilişim Teknolojileri Araştırması. http://www.tuik.gov.tr (Erişim Tarihi: 12.10.2016).

UNESCO, (2003). Developing and Using Indicators of ICT Use in Education. UNESCO Asia and Pacific Regional Bureau for Education, Bangkok, 7-9.

UNESCO, (2006). Using ICT to Develop Literacy. UNESCO Bangkok, 18-21. Williams, L. (2001). ICFT Information Communication and Friendship Technology: Philosophical Issues Relating to the Use of ICT in School Settings. Leask, M. (Ed.), Issues in Teaching Using ICT (p. 4960). London: Routledge.

Yıldırm, A. ve Şimşek, H., (2016). Soysal Bilimlerde Nitel Araştırıma Yöntemleri (10. Baskl), Ankara: Seçkin Yayıncilı.

Zittrain, J. (2008). The Future of the Internet and How to Stop It. London: Yale University Press.

\section{Kaynakça Bilgisi / Citation Information}

Akgül, H. (2017). Nineden-dededen, toruna, bilgi ve iletişim teknojilerine yönelik metaforik algılar. OPUS - Uluslararası Toplum Araştırmaları Dergisi, 7(13), 653-677. 